\title{
Corruption and the impact of democracy
}

\author{
Ina Kubbe ${ }^{1} \cdot$ Annika Engelbert $^{2}$
}

Published online: 3 November 2017

(C) Springer Science+Business Media B.V., part of Springer Nature 2017

Corruption - broadly defined as the misuse of public office for private gains $[1,2]-$ costs every country a large amount of financial, political and social resources every year. Research on the causes, consequences and combat strategies of corruption are manifold and very revealing. Previous studies indicate, for example, that wellestablished democracies show lower levels of corruption than authoritarian regimes or young democracies [3-6]. At the same time, high levels of corruption undermine democracy. By diverting rare resources from disadvantaged people, it damages the rule of law, social justice and lowers the trust of citizens in political institutions and processes $[7,8]$.

The reciprocal democracy-corruption nexus has already been analyzed in several studies and is nowadays well-established [9-15]. Previous research shows that democracy does not guarantee clean and transparent governance at all and democratic systems are still fighting against corruption [16-20], even in countries that are often seen as almost free of corruption. Yet, frequent scandals like in the United Kingdom, Iceland, United States or Spain illustrate that corruption is a serious problem in nearly every state in the world (e.g. [21]).

This Special Issue focuses on the relationship between corruption and the impact of democracy from diverse perspectives and different regions and countries around the world. Specifically, the following articles consider the role of democratic institutions in curbing corruption, the interrelation between democratic values and corrupt behavior, and the importance of corruption in democratization processes in post-conflict states. The findings of this issue illustrate that there is no 'one size fits all' solution for preventing corruption, yet there are certain mechanisms and elements in democratic and democratizing countries that support anti-corruption.

Ina Kubbe

inakubbe@ post.tau.ac.il

Annika Engelbert

annika.engelbert@ ruhr-uni-bochum.de

1 Department of Political Science, Tel Aviv University, Tel Aviv, Israel

2 Law Faculty, Ruhr University Bochum, Universitätsstraße 150, 44801 Bochum, Germany 
Starting with one of the core institutions of democratic political systems, two contributions investigate the legislative power of parliaments in the fight against corruption. In her article "Framing Corruption: How Language Affects Norms", Ramona Zmolnig analyzes the still unexplored relationship between political decision-making and political framing. She examines correlations between the way politicians perceive and communicate corruption and the commitment of these political actors to the legislative fight against corruption in an established democracy like Austria. The study is based on a manual dimension-reduced coding-process of nine years of political communication that refers to corruption in the Austrian National Council. The author indicates that the perception of corruption as an individual misconduct and a weakness of character of certain actors - individuals as well as collectives such as parties - leads to insufficient anti-corruption laws and the prevention of necessary policy reforms in a democratic country as Austria.

Felix Goldberg argues that political scientists still have not agreed upon a conceptual distinction between lobbying and corruption. Most scholars consider these concepts separately and distinguish them by their legality. While influencing political decision making by means of corruption is an illegal act, lobbyism is an accepted way to represent the interests of the business community. However, the boundaries of the two phenomena are not always clear-cut. Therefore, the author provides a systematic differentiation and conceptual comparison between corruption and lobbying. He presents a framework in which both terms can be distinguished based on theoretical considerations in investigating their negative effects to democracy. He argues that lobbying becomes corruption as soon as it is a source of exclusion from a democratic process. Thus, distinguishing lobbying from corruption helps to understand when they substitute each other and when they occur complementarily.

Taking a broader approach, Ina Kubbe's study investigates the influencing factors of corruption in Europe over the period of 1995-2013. Considering corruption as a cultural, multilevel phenomenon, her project proposes the design of models at both the micro and macro levels, allowing for panel-analyses as well as cross- and withinnational comparisons. She shows that formal democratic institutions are inefficient when they lack moral underpinning based on democratic values. Her findings reveal that a bundle of factors adding up to a specific "democratic culture" in Europe that hinders the growth of corruption by generating strong democratic institutions and fostering citizen norms and values aimed at monitoring and sanctioning corrupt actors. The article emphasizes the relevance and need of area- and cultural-specific knowledge of factors affecting corruption.

Investigating the role of power relations in the occurrence of corruption, Miranda Loli discusses the inequality-corruption nexus. Instead of looking at inequality as a consequence of corruption, she focuses on the triggering effects inequality might have on corruption levels, particularly in terms of self-legitimation narratives. Despite the fact that the common definition as an 'abuse' of power removes the possibility of legitimation of corruption, legitimation narratives do exist and they also do appear in various surveys or case studies. Based on Tilly's perspective of inequality to corruption research, this article provides new input for understanding the dynamics of inequality and opportunity hoarding that fuel endemic corruption.

Turning towards developing countries in the initial phases of democratization suffering from high levels of corruption, Ole Frahm analyzes discourses on corruption 
in three oil-rich Sub-Saharan African countries, South Sudan, Ghana and Nigeria, in various stages of democratization, from post-conflict transition to increasingly consolidated democracies. The underlying question guiding his analysis is to evaluate how both the practice and perception of corruption change in the course of democratization. The study juxtaposes empirical findings with theories of the African state and finds neo-patrimonialism and the concept of the gatekeeper state the most satisfactory explanatory models for the sources and types of corruption in African democracies afflicted by the resource curse.

Considered to be both, cause and consequence of violent conflicts, corruption is a serious threat to stability and peace. Anna Schwickerath finalizes the Special Issue by assessing the role of United Nations peacekeeping missions in assisting transition and democratization in post-conflict states. This phase is of particular interest in the field of corruption research, since there is general agreement among scholars that corruption increases during the early stages of transitions. Her article on "Anti-Corruption Norms in Training for United Nations Peacekeeping Operations" examines whether these missions face challenges emanating from corruption. Based on a content analysis of almost 200 United Nations and guidance documents for their peacekeepers, this study contributes to a deeper understanding of peacekeeping and its impact on the fight against corruption.

In sum, this Special Issue on Corruption and the Impact of Democracy reveals that it is absolutely necessary that we consider and include country-specific and cultural contexts and characteristics of societies when we are analyzing corruption and searching for anti-corruption strategies and mechanisms. In all the various contributions it becomes clear that certain norms play a significant role if people act corruptly or not. This implies that we also have to rethink and redefine basic definitions, terms and concepts that are related to and framing corruption - in matured as well as in new democracies, as the studies have indicated.

\section{References}

1. Rose-Ackerman, S. (2008). Corruption. In C. K. Rowley \& F. G. Schneider (Eds.), Readings in public choice and Constitutional Political Economy (pp. 551-566). Boston: Springer US.

2. Transparency International. (2016). What is Corruption? https://www.transparency.org/what-iscorruption/. Accessed 5 Sept 2017.

3. Fjelde, H., \& Hegre, H. (2014). Political corruption and institutional stability. Studies in Comparative International Development, 49(3), 267-299.

4. Kalenborn, C., \& Lessmann, C. (2013). The impact of democracy and press freedom on corruption: Conditionality matters. Journal of Policy Modeling, 35(6), 857-886.

5. Mohtadi, H., \& Roe, T. L. (2003). Democracy, rent seeking, public spending and growth. Journal of Public Economics, 87(3-4), 445-466.

6. Treisman, D. (2000). The causes of corruption: A cross-national study. Journal of Public Economics, 76(3), 399-457.

7. Holmes, L. (2006). Rotten states? Corruption, post-communism, and neoliberalism. Durham: Duke Univ. Press.

8. Jong-sung, Y., \& Khagram, S. (2005). A comparative study of inequality and corruption. American Sociological Review, 70(1), 136-157.

9. Kolstad, I., \& Wiig, A. (2016). Does democracy reduce corruption? Democratization, 23(7), 1198-1215.

10. Kubbe, I. (2015). Corruption in Europe: Is it all about democracy? Baden-Baden: Nomos Verlagsgesellschaft. 
11. Montinola, G. R., \& Jackman, R. W. (2002). Sources of corruption: A cross-country study. British Journal of Political Science, 32(1), 147-170.

12. Olteanu, T. (2012). Korruption in der Demokratie. In T. Olteanu (Ed.), Korrupte Demokratie? (pp. 267294). Wiesbaden: VS Verlag für Sozialwissenschaften.

13. Rock, M. T. (2009). Corruption and democracy. The Journal of Development Studies, 45(1), 55-75.

14. Sung, H.-E. (2004). Democracy and political corruption: A cross-national comparison. Crime, Law and Social Change, 41(2), 179-193.

15. Warren, M. E. (2004). What does corruption mean in a democracy? American Journal of Political Science, 48(2), 328-343.

16. Ferrin, M. (2016). An empirical assessment of satisfaction with democracy. In M. Ferrin \& H. Kriesi (Eds.), How Europeans view and evaluate democracy (pp. 283-306). Oxford: Oxford University Press.

17. McMann, K. M., Seim, B., Teorell, J. \& Lindberg, S. I. (2017). Democracy and Corruption. A Global Time-Series Analysis with V-Dem Data. V-Dem Working Paper 2017:43. https://ssrn. com/abstract=2941979. Accessed 5 Sept 2017.

18. Seldadyo, H., \& De Haan, J. (2011). Is corruption really persistent? Pacific Economic Review, 16(2), 192-206.

19. Shen, C. (2005). Corruption, democracy, economic freedom, and state strength: A cross-national analysis. International Journal of Comparative Sociology, 46(4), 327-345.

20. Uslaner, E. M., \& Rothstein, B. (2016). The historical roots of corruption: State building, economic inequality, and mass education. Comparative Politics, 48(2), 227-248.

21. Gamir, A. F. (2015). Mapping High-Level Corruption Risks in Spanish Public Procurement. http://www. crcb.eu/wp-content/uploads/2015/02/Gamir_Corruption-in-Spanish-PP_v2_2015Feb.pdf. Accessed 5 Sept 2017. 